\title{
Assessing Ecosystem Restoration Alternatives in Eastern Deciduous Hardwood Forests Using Avian Nest Survival
}

\author{
Henry M. Streby ${ }^{1,2}$ and Donald B. Miles ${ }^{* 1}$ \\ ${ }^{1}$ Department of Biological Sciences, Ohio University, Athens, OH 45701, USA \\ ${ }^{2}$ Department of Fisheries, Wildlife and Conservation Biology, University of Minnesota, St. Paul, MN 55108, USA
}

\begin{abstract}
The effects of anthropogenic forest disturbance on avian populations are only starting to be understood, with most research focusing on community richness and species abundance. Monitoring nesting survival is becoming an important and increasingly reliable method for assessing habitat quality. We investigated nest survival and Brown-headed Cowbird nest parasitism of 18 Neotropical migratory bird species in experimentally managed mixed-oak forests in southeast Ohio. We monitored nests during one pre-treatment year and four post-treatment years in four treatment plots: thin, burn, thin + burn, and unmanipulated control. Nesting activity was lower in the first two post-treatment years, but returned to pre-treatment levels in the last two post-treatment years. Overall post-treatment nesting success in the thin and thin + burn treatments exceeded that in the control and burn plots. Ground and shrub nesting species responded negatively to burning alone, but were not affected by the other treatments. Understory nesting success was initially lower in the burn and thin + burn treatments than in the thin only treatment, but increased in the thin and thin + burn treatment in the final two years. Furthermore, we observed bird species nesting in the thin and thin + burn treatments in the final two years that had not been recorded in the previous three years. Hence, the thinned habitats attracted secondary scrub nesting species. Nest heights were significantly higher in burn and thin + burn treatments. We did not detect Brown-headed Cowbird parasitism until the third and fourth years post-treatment, but nest parasitism was still low at $4.1 \%$ of active nests. Our results suggest that combining selective harvests (thinning) with prescribed fire is the best of these forest management plans when considering avian nest survival.
\end{abstract}

Keywords: Daily survival rate, nest success, mechanical thinning, prescribed fire, deciduous forest.

\section{INTRODUCTION}

Populations of Neotropical migratory songbirds have been in decline for over half a century [1-3]. In North American breeding populations, declines have been well documented for forest interior species $[4,5]$ and more recently for grassland nesting species [6]. Decreased densities of forest interior songbirds have been attributed to the multiple factors. One reason for these declines is the loss of breeding habitat due to agriculture and development [7]. A second effect is the fragmentation of forests and the resulting increase in forest edge. An alternative factor is the turnover in forest composition and physical structure as a consequence of the long history of fire suppression. Modern approaches to forest ecosystem management often mitigate this last factor by altering fuel loads by prescribed fires or selective thinning. The latter approach is designed to create gaps in closed canopy forests to facilitate the recruitment of shade intolerant tree species. This manipulation of forest structure alters nesting habitat, food availability and predator abundance relative to unperturbed forests [8]. Much attention has been paid to the response and recovery of populations after burning, clearcuts, or thinning [9-12], with a focus on community richness and species density [13-17].

*Address correspondence to this author at the Department of Biological Sciences, Ohio University, Athens, OH 45701, USA;

Tel: 740-593-2317; Fax: 740-593-0300;

E-mail: dmiles2@ohio.edu
Although monitoring trends in species richness and abundance may be the most convenient method for assessing avian habitat quality following anthropogenic disturbance, it should be complemented by measures of reproductive success [18, 19]. Modified forests and edge-dominated habitat can act as ecological traps [19-21], attracting birds to nest at higher densities in a lower quality habitat, making nesting success an important measure of habitat quality [18, 21]. Little is known about the effects of perturbations such as prescribed fires and selective thinning on the nesting success of avian communities, and few studies have applied a rigorous experimental design including a pre and posttreatment dataset [22].

\section{REGIONAL FIRE HISTORY AND ALTERNATIVE FOREST METHODS}

Frequent, low intensity fires played an integral role in shaping and maintaining the oak dominated forests of much of the Midwestern United States [23, 24]. The prevention of wildfire has been a widespread practice of forest management across the United States dating back to the early 1930's $[25,26]$. This practice has been successful in most areas including the forests of southern Ohio. Fire scar patterns from the mixed oak forest of Vinton County, Ohio show that small fires have occurred at less than half the frequency since 1930 than in previous decades, and large fires have nearly been excluded all together [27]. During these decades, mixed oak forests of the Ohio Valley accumulated ground fuels and developed dense canopies, 
which facilitated more shade tolerant tree species to dominate the understory [28]. Continued fire suppression is predicted to reshape the eastern deciduous forest with shade tolerant beeches and maples eventually dominating the landscape, replacing the less shade tolerant, historically dominant oaks and hickories [23]. The turnover in forest species composition and physical structure may affect habitat suitability for nesting by birds [29].

A recent shift in management policy recognized the importance of fire in maintaining both an economically and ecologically sound forest landscape. Agencies are now experimenting with methods for recreating the effects of many lost decades of fire. Prescribed burning of leaf litter and fallen fuels, shelterwood harvests and other approaches for regeneration (e.g., partial harvests) are recent methods employed with these intentions. Whereas these treatments may create a similar structure to that left by wildfire, biologists are concerned with the immediate and long-term effects on resident wildlife. Government sponsored forestry studies that introduce broad habitat modifications allow for the effects on wildlife to be studied on a much larger scale than any individual researcher could create [30]. The National Fire and Fire Surrogates Study (FFS) is one such program designed to determine the best management practices for maintaining healthy forests at 13 sites across the United States [31]. Mechanical fuel reduction (Partial Harvests) and prescribed burning are being introduced to forests in which there have been fire prevention efforts for varying lengths of time. The Ohio Hills site of the FFS is located on two 100 ha experimental replicates in the mixed oak forests of Vinton County in southeast Ohio [32]. The purpose of the FFS study at the Ohio Hills site is to test the effects of partial harvests and prescribed burning on the regeneration of oak (Quercus spp.) trees. Combining partial harvests with a subsequent prescribed fire is a relatively new technique. Lanham et al. [33] described the potential avian community response to similar shelterwood-burn techniques, but ours are the first empirical results reported on the effects of such a technique on avian nesting success.

\section{OVERVIEW OF EFFECTS OF BURNS AND THINNING ON AVIAN NEST SURVIVAL}

Data describing the effects of large-scale forestry treatments such as prescribed burning and partial harvests on avian nesting survival are scant, but do suggest a heterogeneous response among species and nesting guilds $[8$, 34, 35]. Ground and shrub nesting migrants were less successful in burned Indiana forests than in control plots [36]. In contrast, daily nest survival in burned habitats did not differ from unburned habitats in Dark-eyed Juncos (Junco hyemalis [37]) in ponderosa pine (Pinus ponderosa) or for Wood Thrushes nesting in deciduous forests in southeastern Ohio [38].

Nest success did not differ in a small sample of nests monitored in clearcut, shelterwood harvested, and mature forests in New Hampshire [39]. Similarly, nest success did not differ for understory nesting species between two-age thinned treatments and control forest in West Virginia [40], or for birds in either nesting guild in thinned forests in southern Illinois [41]. Barber et al. [42] found that nesting success in some shrub nesting species decreased in thinned pine plantations in relation to previous other published studies, whereas Bourque and Villard [43] found that selective cutting lowered Ovenbird (Seiurus aurocapillus) nesting success. In Missouri Ozark forests, uneven-aged thinning also resulted in lowered nesting success for ground and shrub nesting species, while the nesting success of the understory nesting Wood Thrush (Hylocichla mustelina) was unaffected [22]. Wood Thrushes occurred in more frequently in partial harvest sites than three other thrush species [8]. In addition, nest survival of Wood Thrushes exceeded those of other thrushes in partial harvest treatments [8].

Despite the rise in use of prescribed burning and partial harvesting methods for managing hardwood forest ecosystem dynamics, there are limited examples of replicated experimental studies that monitor the responses of wildlife to these treatments. We present the results of a before-after, control-impact (BACI) experiment examining the effects of the prescribed burns and partial harvesting on the nesting success of Neotropical migratory birds within the mixed deciduous hardwood forest of southeast Ohio. We summarize trends over five years, one baseline (pretreatment) year and four post-treatment years of nest monitoring, including daily survival rates, estimated nesting success, nest height, and Brown-headed Cowbird (Molothrus ater) parasitism. Based on previous results, we hypothesized lowered nesting success for ground and shrub nesting birds in the years immediately following treatment in all three treatments compared to control, while the nesting success of the understory nesting guild would likely be unaffected. We also hypothesized that nesting success for both guilds in all treatments would be similar to control after a period of 3- 4 years post treatment. Because prescribed fire alters the litter and understory structure, we included nest height as a response variable. We predicted nests to be situated higher in the burned plots. Moreover, the partial harvests created gaps within a forest rather than increasing edge habitats. However, the slash and appearance of early successional vegetation within the gaps should favor nest survival for species in both nesting guilds. The FFS experimental forests included in this study are bordered by contiguous control forest, with little or no edge. Consequently, we predicted that brood parasitism by Brown-headed Cowbirds would be low or absent throughout the study.

\section{MATERIALS AND METHODOLOGY}

\section{Study Area}

We monitored nests in locations that comprise the Ohio Hills Site of the National Fire and Fire Surrogate Network. The replication within the Raccoon Ecological Management Area (hereafter REMA) $\left(39^{\circ} 11^{\prime} \mathrm{N}, 82^{\circ} 22^{\prime} \mathrm{W}\right)$ and the replication within Zaleski State Forest (hereafter Zaleski) $\left(39^{\circ} 21^{\prime} \mathrm{N}, 82^{\circ} 22^{\prime} \mathrm{W}\right)$ are both located in Vinton County, OH. Both replicates are located on the unglaciated Allegheny Plateau of southern Ohio. The climate of the region is cool, temperate with mean annual precipitation of $1024 \mathrm{~mm}$ and mean annual temperature of $11.3^{\circ} \mathrm{C}$ [27]. The forests of the region developed between 1850 and 1900, after the cessation of cutting for the charcoal and iron industries. The current canopy composition differs little from that recorded in the original land surveys of the early 1800 's. The most abundant species in the current canopy are white oak (Quercus alba), 
chestnut oak ( $Q$. prinus), hickories (Carya spp.), and black oak (Q. velutina) [44].

\section{Experimental Design}

We estimated nest survival in response to prescribed fire and mechanical thinning using a before-after/control-impact design. Each of the two study sites was treated as a block $(\mathrm{n}=2$ replicates) and one of four fuel reduction treatments was randomly implemented within each block: untreated control, partial harvest, i.e., thinning from below to a basal area comparable to that prior to Euro-American settlement, prescribed burn, and burn + thin [31]. The area of each treatment unit ranged from $19-26$ ha with an additional buffer of approximately $10 \mathrm{ha}$. Site selection of the treatment unit included all combinations of elevation, aspect, and soil, and approximated the local watershed scale in area. Analysis of fire scars in stems of trees that were cut as part of plot establishment indicated that fires were frequent (return intervals of $8-15$ years) from 1875 to 1930 . In contrast, few fires occurred after the onset of fire suppression activities in the early 1930's (T. Hutchinson, U.S.D.A. Forest Service, personal communication). Both the treatment unit and its corresponding buffer received the experimental treatment. US Forest Service field crews geo-referenced each replicate with a system of grid points spaced $50 \mathrm{~m}$ apart.

We began monitoring nests 1 year prior to the application of treatments (= pre-treatment year) in 2000. Thinning took place between September 2000 and April 2001, and created a mosaic of gaps, while retaining mature oaks. The goal was a residual basal area of approximately $14 \mathrm{~m}^{2} / \mathrm{ha}$, but this goal was not achieved at any of the study sites. Thinning removed an average of $27.9 \%$ of the basal area and left an average of $20.9 \mathrm{~m}^{2} / \mathrm{ha}$ in residual basal area (D. Yaussy, U.S.D.A. Forest Service, personal communication). In addition, the cut crowns from partial harvesting, left on the forest floor, increased the amount of fallen, coarse woody debris. Partial harvests in those units subjected to the thin and burn treatment occurred at least two months prior to burning.

Fire technicians completed the prescribed burns during March and April of 2001 after the thinning treatment. These dormant season fires mimicked the predominant mode of natural fires in the region. Flame lengths varied from $<20 \mathrm{~cm}$ to approximately $2 \mathrm{~m}$ at REMA (M. Bowden, Ohio Division of Forestry, personal communication). These fires consumed unconsolidated leaf litter and fine woody (1h) fuels while only charring the majority of the coarse woody fuels.

\section{Nest Survival and Success}

We focused nest searching in the REMA and Zaleski replicate forests of the Ohio Hills FFS site. Nest searching began mid-April- early May and continued through July in most years. We surveyed for nests for one pre-treatment year, 2000 and for four post-treatment years (2001- 2004). Each of the treatment plots was systematically searched at least 6 times each year. Each person followed a predetermined route along a series of grid points. Surveys involved an equal number of person hours within each year and entailed walking through the treatment plot and noting activity adjacent to each grid point. Nest searches were initiated between 06:30- 07:30 and continued until midday, when bird activity tapered. We used standardized protocols for locating nests $[45,46]$, which were modified for the FFS program. Most nests were located by observation of the behavior of the parent (following parent to the nest, flushing incubating or brooding parent off nest, parent feeding young), behavior of the young, or searching areas where nests were located in the previous year. We monitored nests and recorded development following the Breeding Biology Research and Monitoring Database (BBIRD) [45, 46] and FFS protocols. Different paths were taken to and from nests during each observation to avoid attracting predators [45]. At each visit we noted the amount of adult activity around the nest. Absence of adult activity on a given visit (during a 30 minute observation interval) suggested that the adults abandoned the nest. We verified whether the adults abandoned the nest by repeat visits every $2 \mathrm{~d}$. We recorded the final fate of a nest as either successful (presence of fledglings near the nest or egg shell fragments) or failed. We also noted the likely causes for nest failure: e.g., predation (nest torn up, holes in nest), adult mortality, and accidental destruction of nest (weather related).

When observing nests located between eye level and 10 meters we used a mirror mounted on a telescoping pole or the Treetop Peeper II ${ }^{\circledR}$, (Sandpiper Technologies) a livefeed digital camera mounted on a telescoping pole with a monitor on the base segment. Once discovered, each nest was visited one to three times every seven days and as often as possible when an event (laying, hatching, or fledging) was predictably approaching (mean visitation interval $=4.8$ days). We measured the height of nest placement upon discovery of each nest. We organized species into either the ground/shrub or understory nest guild based on nest height records for each species [47]. We validated the categorical placements using our field observations.

\section{Estimation of Daily Survival Rate}

We employed recently developed analytical methods to estimate daily nest survival and nest success in relation to treatment. Shaffer [48] provided a thorough review of the statistical analysis of nesting success, beginning with Mayfield [49]. Several improvements have been made to this estimator to account for variable visitation intervals $[50,51]$ and allowing for estimates to be compared between groups [52]. Logistic Regression models allow for the inclusion of fixed effects and covariates (e.g., prescribed fire, nest height, see $[53,54])$ to determine multiple factors affecting nest success. We used a Mayfield logistic regression [55] and a logistic exposure model [48] to estimate the effects of fire and fire surrogates treatments on nest success and daily nest survival. We included the logistic exposure model because it allows for variable lengths in visitation intervals [48]. Unlike logistic regression models using Mayfield estimates, the logistic exposure model requires no assumptions about when nest failures occur, and accounts for the bias in varying exposure interval length. In comparative analyses these methods provided similar results to those of logistic regression and other models [48, 55, 56, 57].

\section{Statistical Analyses}

We evaluated differences in nest success with respect to fire and thinning using a Mayfield Logistic Regression to estimate daily survival rates (DSR) as implemented using SAS PROC LOGISTIC $[55,58]$. We used the event/trials 
syntax for specifying the response variable. The events value is the positive response. Here we coded nest success as 0 and failure as 1 . Trials are the number of exposure days for each nest. Our models included the main effects burn, thin and the interaction between burn and thin with nest survival as a response variable pre- and post-treatment. We first evaluated whether the units differed in nest survival before the application of any treatments. This evaluated whether any spatial heterogeneity existed in nest survival. Next, we compared nest survival before treatment with an overall treatment effect by pooling all post-treatment years. We next compared the effects of treatment after the first two years (initial response) and the last two years (extended) of the experiment.

\section{Logistic Exposure Estimates of Daily Survival Rate}

Logistic exposure is a generalized linear model that consists of three parts: 1) a binomial response distribution (success or failure); 2) a predictor function; and 3) a logit link function. We modified the PROC GENMOD statements presented in [48] to estimate daily survival rates, the corresponding estimates of nesting success, and 95\% confidence intervals. We first tested for differences among the treatment plots during the pre-treatment year. Next we evaluated an overall effect of treatment on nest success. We then compared the effects of each treatment for the first two treatment years (initial response) and again for the last two treatment years (extended response). The division between initial response and extended response reflects changes in the avian community composition that occurred in the $3^{\text {rd }}$ and $4^{\text {th }}$ post treatment years (Miles, unpublished data).

\section{RESULTS}

\section{Nest Numbers and Species}

We detected and monitored 18 Neotropical migratory bird species nesting in the two replicate sites over the 5-year period (Table 1). This total included ground/shrub (9) and understory (9) species. However, four species had only a single nest detected during the 5-year study. In addition, we excluded species observed nesting in the overstory, because nest monitoring was not as comprehensive. Overall we discovered 238 nests, but 22 belonged to overstory species. We ultimately followed 216 nests, but only 208 active nests had sufficient data to include in our analyses. Therefore, we censored thirty nests, because of their unknown status. The species with the highest number of nests in the study were Acadian Flycatcher (Empidonax virescens), Eastern Phoebe (Sayornis phoebe), Red-eyed Vireo (Vireo olivaceus), Wood Thrush (Hylocichla mustelina), Worm-eating Warbler (Helmitheros vermivora), Ovenbird (Seiurus aurocapillus) and Scarlet Tanager (Piranga olivacea). These species accounted for 187 nests or $80 \%$ of the data (Table 2). We had 863 nest observation days in 2000 and 2222 during 2001- 2004 (mean $=556 /$ year $)$.

We followed 68 nests during the pre-treatment year and 140 in the period 2001- 2004 (Table 3). We discovered and monitored only 43 nests in the first two years post-treatment and 97 in the final two years. The low numbers of nests in the first two years was not an artifact of variable search effort, but reflected lower numbers of species nesting in the
Table 1. Nesting Species of Neotropical Migratory Birds Detected During the Fire and Fire Surrogates Study (2000- 2004). Nesting Guild and Number of Nests are also Given. Nest Guilds are $U=$ understory, $G / S$ $=$ Ground $/$ Shrub

\begin{tabular}{|l|c|c|}
\hline \multicolumn{1}{|c|}{ Species } & $\begin{array}{c}\text { Nest } \\
\text { Guild }\end{array}$ & $\begin{array}{c}\text { Number } \\
\text { of Nests }\end{array}$ \\
\hline \hline Yellow-billed Cuckoo (Coccyzus americanus) & $\mathrm{U}$ & 6 \\
\hline Ruby-throated Hummingbird (Archilochus colubris) & $\mathrm{U}$ & 3 \\
\hline Eastern Wood-Pewee (Contopus virens) & $\mathrm{U}$ & 3 \\
\hline Acadian Flycatcher (Empidonax virescens) & $\mathrm{U}$ & 28 \\
\hline Eastern Phoebe (Sayornis phoebe) & G/S & 46 \\
\hline Red-eyed Vireo (Vireo olivaceus) & $\mathrm{U}$ & 21 \\
\hline Wood Thrush (Hylocichla mustelina) & $\mathrm{U}$ & 63 \\
\hline Gray Catbird (Dumatella carolinensis) & G/S & 1 \\
\hline Blue-winged Warbler (Vermivora pinus) & G/S & 1 \\
\hline Worm-eating Warbler (Helmitheros vermivora) & G/S & 9 \\
\hline Ovenbird (Seiurus aurocapillus) & G/S & 8 \\
\hline Kentucky Warbler (Oporornis formosus) & G/S & 2 \\
\hline Hooded Warbler (Wilsonia citrina) & G/S & 2 \\
\hline Summer Tanager (Piranga rubra) & U & 1 \\
\hline Scarlet Tanager (P. olivacea) & U & 12 \\
\hline Eastern Towhee (Pipilo erythrophthalmus) & G/S & 4 \\
\hline Indigo Bunting (Passerina cyanea) & G/S & 5 \\
\hline Baltimore Oriole (Icterus galbula) & $\mathrm{U}$ & 1 \\
\hline
\end{tabular}

treatment plots. The numbers of nests for ground and shrub nesting species were lowest in the burned plots (burn and thin + burn treatment). In contrast, species nesting in the understory strata had fewer nests in the thin treatments (thin and thin + burn treatments). Number of nests rebounded by the third and fourth years post-treatment. However, the greatest increase in nest numbers occurred in the thin and thin + burn treatments for the ground/scrub nesting species (Table 3).

\section{Daily Survival Rate and Estimated Nest Success}

The pooled daily survival rate in the pre-treatment year was approximately $97 \%$, but estimated nest success was only $38 \%$ (Table 4). Overall daily survival rates for the posttreatment years were slightly higher, $98 \%$, but not significantly so. Estimated nest success from 2001- 2004 was 56.1 percent, which was significantly different from the pre-treatment value $(P<0.05)$.

\section{Mayfield Logistic Regression of Daily Nest Survival}

Nest survival did not differ among the treatments during the baseline survey in $2000\left(\chi^{2}=0.12\right.$, $\left.\mathrm{df}=3, P=0.98\right)$. Furthermore, the main effects of burn, thin and their interaction was not significant. Overall nest survival (pretreatment versus all post-treatment years) was highest in the thin treatment $\left(\beta=-0.21, \chi^{2}=0.12, \mathrm{df}=1, P=0.05\right)$. We 
Table 2. Number of Nests Monitored and Average Nest Success (in Parentheses) in the Pre-Treatment Year, and the Burn, Thin, Thin + Burn and Unmanipulated Control Plots for 10 Neotropical Migratory Bird Species. Numbers of Nests and Nest Success are Presented for the Pre-Treatment Year $($ Baseline $=2000)$ and Post-Treatment Years (2001- 2004)

\begin{tabular}{|c|c|c|c|c|c|c|}
\hline \multirow{2}{*}{ Species } & \multirow{2}{*}{$\frac{\text { Pre-Treatment }}{(2000)}$} & \multicolumn{5}{|c|}{ Post-Treatment (Cumulative Nests 2001- 2004) } \\
\hline & & Control & Burn & Thin & Thin + Burn & Total \\
\hline \multicolumn{7}{|l|}{ UNDERSTORY } \\
\hline Acadian Flycatcher & $16(0.49)$ & $4(0.75)$ & $5(0.20)$ & $2(0.50)$ & $1(1.00)$ & $12(0.50)$ \\
\hline Red-eyed Vireo & $15(0.85)$ & $3(0.67)$ & $1(0.00)$ & $1(0.00)$ & $1(1.00)$ & $6(0.50)$ \\
\hline Wood Thrush & $17(0.57)$ & $20(0.55)$ & $12(0.88)$ & $6(0.83)$ & $8(0.67)$ & $46(0.53)$ \\
\hline Scarlet Tanager & 0 & 0 & $4(0.50)$ & $4(0.50)$ & $4(1.00)$ & $12(0.76)$ \\
\hline Totals & $48(0.69)$ & $27(0.59)$ & $22(0.52)$ & $13(0.64)$ & $14(0.90)$ & $76(0.65)$ \\
\hline \multicolumn{7}{|l|}{ GROUND/SHRUB } \\
\hline Eastern Phoebe & $13(0.39)$ & $6(0.83)$ & $9(0.67)$ & $6(0.33)$ & $12(0.67)$ & $33(0.61)$ \\
\hline Ovenbird & $3(0.60)$ & $4(0.25)$ & 0 & 0 & $1(1.00)$ & $5(0.80)$ \\
\hline Worm-eating Warbler & $1(1.00)$ & $1(1.00)$ & $3(0.00)$ & $3(1.00)$ & $1(1.00)$ & $8(0.63)$ \\
\hline Eastern Towhee & 0 & 0 & $1(1.00)$ & $2(0.50)$ & $1(1.00)$ & $4(0.75)$ \\
\hline Indigo Bunting & 0 & 0 & 0 & $1(1.00)$ & $4(0.75)$ & $5(0.80)$ \\
\hline Kentucky Warbler & 0 & 0 & 0 & $1(1.00)$ & $1(1.00)$ & $2(1.00)$ \\
\hline Totals & $17(0.35)$ & $11(0.64)$ & $13(0.50)$ & $13(0.64)$ & $20(0.77)$ & $57(0.67)$ \\
\hline COMBINED & $65(0.60)$ & $38(0.61)$ & $33(0.51)$ & $26(0.83)$ & $34(0.69)$ & $133(0.52)$ \\
\hline
\end{tabular}

Table 3. Number of Active Nests and Observation Days (in Parentheses) Monitored in Each Treatment for Five Years in the Fire and Fire Surrogates Experimental Plots in Southeast Ohio

\begin{tabular}{|c|c|c|c|c|c|c|}
\hline \multirow{2}{*}{ Treatment } & \multicolumn{6}{|c|}{ Year } \\
\hline & $\mathbf{G} / \mathbf{S}^{*}$ & $\mathbf{U}^{* *}$ & G/S & $\mathbf{U}$ & G/S & $\mathbf{U}$ \\
\hline Control & $3\left(48^{\mathrm{a}}\right)$ & $6(80)$ & $3(38)$ & $9(166)$ & $8(159)$ & $18(315)$ \\
\hline Burn & 3 (49) & 13 (166) & $4(85)$ & $15(210)$ & $8(193)$ & $8(93)$ \\
\hline Thin + Burn & $6(105)$ & 14 (139) & $1(3)$ & $4(51)$ & $21(341)$ & $16(223)$ \\
\hline Totals & 17 (271) & $51(592)$ & $10(145)$ & 33 (489) & $49(888)$ & $48(700)$ \\
\hline
\end{tabular}

${ }^{*} \mathrm{G} / \mathrm{S}=$ Ground/Shrub nest guild

${ }^{* *} \mathrm{U}=$ Understory nest guild

${ }^{a}$ Number of days from commencement of egg laying or discovery of active nest to estimated fledge or failure.

found no differences in daily nest survival among the treatments during the first 2 years post-treatment $\left(\chi^{2}=0.08\right.$, $\mathrm{df}=3, P=0.98)$. The highest values for daily nest survival occurred in the thin + burn treatments during the last two years of the study $\left(\beta=-0.40, \chi^{2}=3.9, \mathrm{df}=1, P=0.04\right)$.

\section{Logistic Exposure Estimates of Daily Survival Rate}

Daily survival rates were uniformly high $(<90 \%)$ for all treatments regardless of the time period or nesting guild (Table 4). However, estimated nest success varied with treatment. Estimates of total nesting success were not different from control in either the thin or the burn treatment in the initial and extended response years (Fig. 1). Estimated nesting success in the thin + burn treatment $(78.0 \%)$ was significantly greater than that of the control and both individual treatments in the extended response years (Fig. 1).

Table 4 shows pre-treatment nesting success rates for each nesting guild followed by the initial response (20012002) and the extended response (2003-2004). We had insufficient numbers of nests and exposure days for species in the ground/shrub nest guild to determine daily survival rates and nest success during the first two years posttreatment (2001- 2002). Similarly, the 95\% confidence intervals for this guild in the control treatment ranged from $0.0 \%-100.0 \%$ for the same reason. The extended response within the ground/shrub nest guild was no different among the control, thin, and thin + burn treatments. Nesting success was however significantly lower in the burn treatment than 
Table 4. Daily Survival Rate, Estimated Nesting Success and 95\% Confidence Intervals Derived from 208 Nests Monitored in the Fire and Fire Surrogates Experimental Forests in Southeast Ohio. Values were Calculated Using the Logistic Exposure Analysis

\begin{tabular}{|c|c|c|c|c|c|}
\hline Guild & Period & Treatment & Daily Survival & Estimated Nest Success & $95 \% \mathrm{CI}$ \\
\hline Combined & 2000 & Pre-treatment & 0.966 & 0.384 & $0.322-0.456$ \\
\hline \multirow{6}{*}{ Ground/Shrub } & \multirow{3}{*}{$2001-2002$} & Control & 0.908 & 0.067 & $0.000-1.000$ \\
\hline & & Thin & & & \\
\hline & & Burn & 0.974 & 0.483 & $0.293-0.789$ \\
\hline & \multirow{3}{*}{ 2003-2004 } & Control & 0.994 & 0.840 & $0.702-1.000$ \\
\hline & & Thin & 0.983 & 0.615 & $0.475-0.793$ \\
\hline & & Thin + Burn & 0.985 & 0.665 & $0.550-0.802$ \\
\hline \multirow{6}{*}{ Understory } & \multirow{2}{*}{$2001-2002$} & Thin + Burn & 0.975 & 0.487 & $0.437-0.543$ \\
\hline & & Burn & 0.964 & 0.356 & $0.246-0.511$ \\
\hline & \multirow{4}{*}{$2003-2004$} & Control & 0.976 & 0.501 & $0.401-0.625$ \\
\hline & & Thin & 0.950 & 0.238 & $0.128-0.436$ \\
\hline & & Thin + Burn & 1.000 & 1.000 & $1.000-1.000$ \\
\hline & & Burn & 0.963 & 0.351 & $0.205-0.595$ \\
\hline
\end{tabular}

in the control for this guild in the extended response years (Fig. 2).

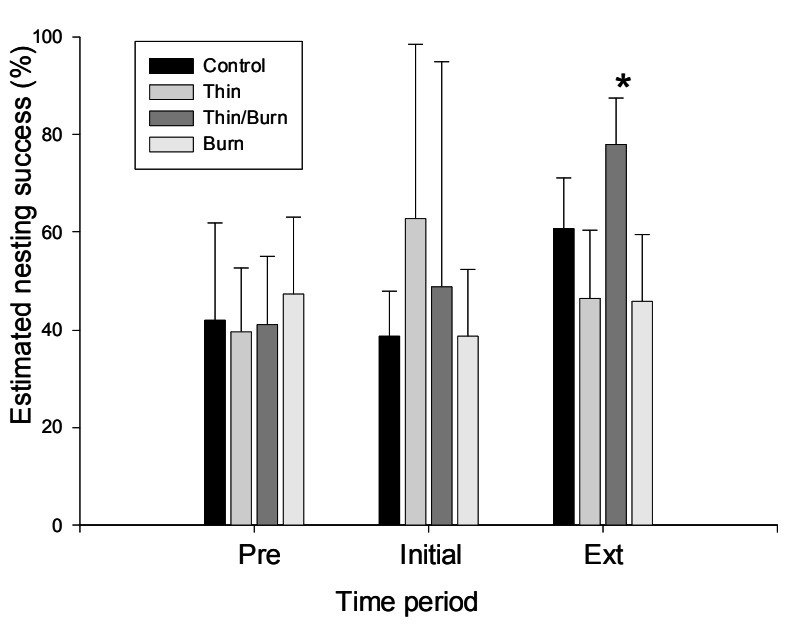

Fig. (1). Nesting success estimates and $95 \%$ confidence limits derived from logistic exposure model for all migrant nests monitored in the Fire and Fire Surrogates experimental study in the Ohio Hills site Ohio $($ Pre $=$ pre-treatment 2000, Initial $=$ acute response 2001-2002, Ext $=$ Extended response 2003-2004, Asterisk $=$ Significantly higher estimated nesting success than the other three treatments).

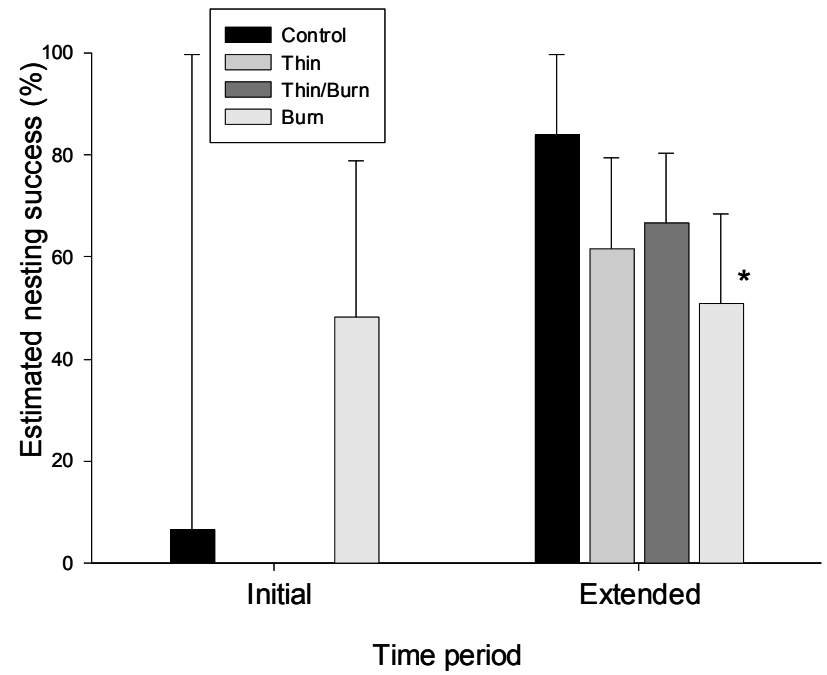

Fig. (2). Nesting success estimates and standard deviation derived from logistic exposure model for ground and shrub nests monitored in the Fire and Fire Surrogates experimental study at the Ohio Hills site (Initial $=$ Initial response 2001-2002, Ext: Long-term response 2003-2004, Asterisk = Significantly lower estimated nesting success than control).

Nesting success for each treatment in the initial response period did not differ from that of the control within the 
understory nest guild (Fig. 3). In the extended response years, estimated nesting success for this guild in the thin only and burn only treatments did not differ from control. However, estimated nesting success for understory nesters in the thin + burn treatment during this period was higher than all the other plots, with exposure data from 16 nests yielding no losses.

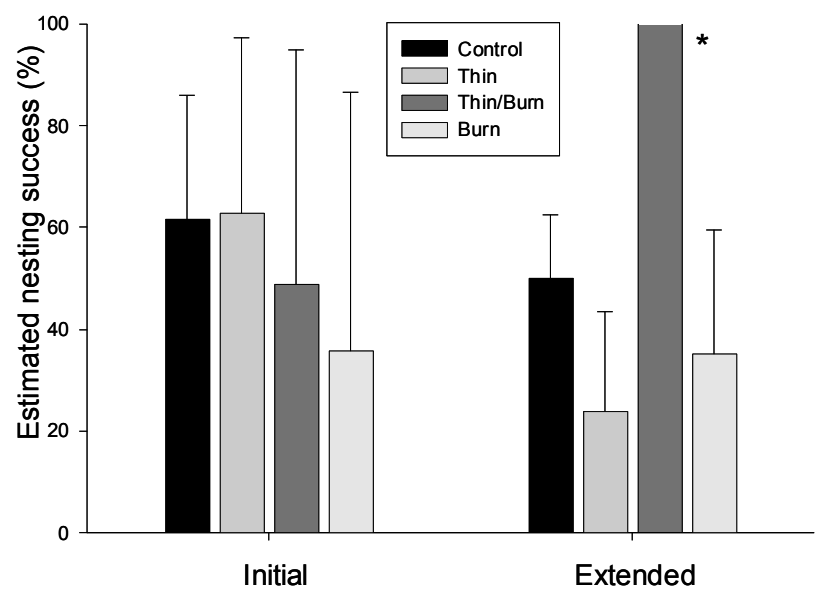

Time period

Fig. (3). Nesting success estimates and standard deviation derived from logistic exposure model for understory nests monitored in the Fire and Fire Surrogates experimental forests of southeast Ohio (Initial $=$ Initial response 2001-2002, Ext $=$ Extended response 2003-2004, Asterisk $=$ Significantly higher estimated nesting success than the other three treatments).

\section{Nest Height}

We tested for differences in nest height using a twofactor ANOVA with treatment and guild used as factors. The response to the treatments differed with nesting guild (Fig. 4). Average nest height was higher in the thin and thin + burn plots for species in the ground/shrub guild $\left(\mathrm{F}_{3,72}=3.47\right.$, $\mathrm{P}<0.01$, Fig. 4A). In contrast, nest height was higher in the burn and thin + burn plots for species in the understory guild $\left(\mathrm{F}_{3,128}=18.06, \mathrm{P}<0.001\right.$, Fig. 4B $)$.

\section{Brown-headed Cowbird Nest Parasitism}

Brown-headed Cowbirds parasitized no nests in the pretreatment year or in the two years of the initial response. We detected a low incidence of nest parasitism during the last two years of the study. We discovered only four nests with evidence of Brown-headed Cowbird nest parasitism, which represents an incidence of 4.1\% (4/97 nests). The species parasitized included an Ovenbird and Red-eyed Vireo nest in the thin + burn treatment, and two Worm-eating Warbler nests in the burn treatment. Three of these nests successfully fledged the Brown-headed Cowbird offspring and the nesting species offspring, while one Worm-eating Warbler nest was lost due to predation.

\section{DISCUSSION}

Past studies of avian responses to forestry management techniques usually focused on either mechanical thinning or prescribed fire and rarely in a before-after, control-impact (BACI) design. Species nesting in the thin and thin + burn
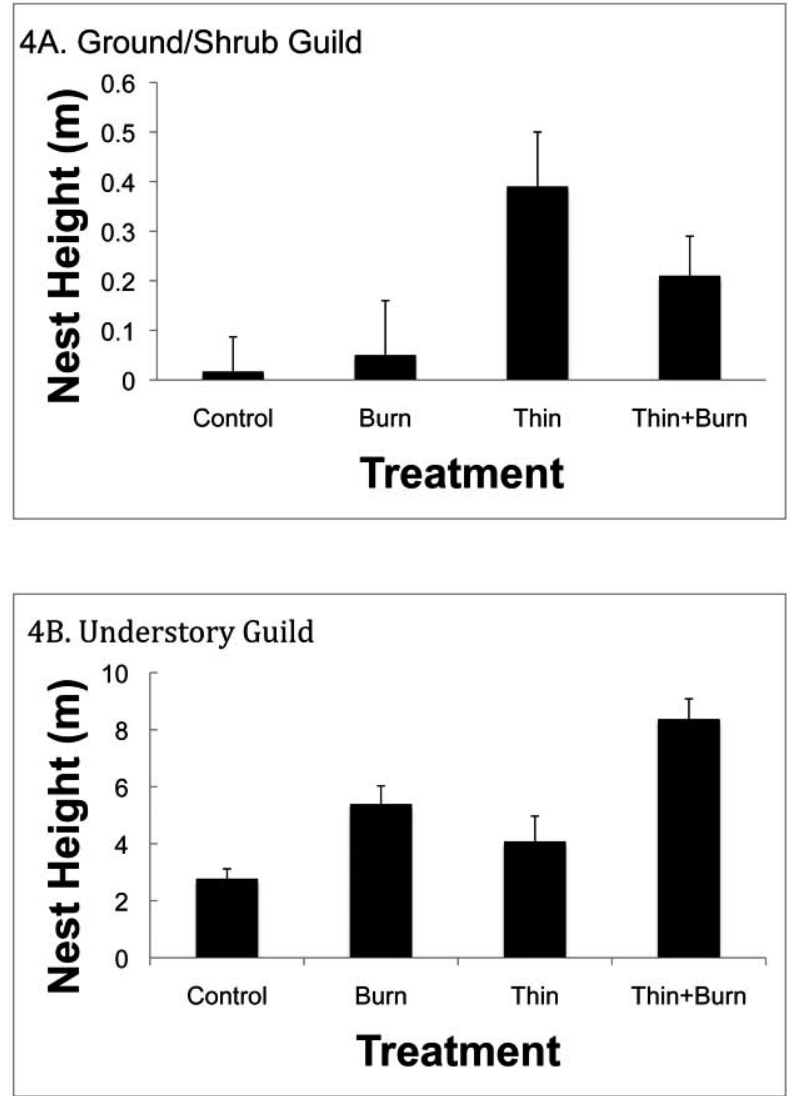

Fig. (4). Variation in nest height observed in each of the Fire and Fire Surrogates treatments. A. Nest heights recorded for species in the ground/shrub nest guild. B. Nest heights recorded for species in the understory nest guild. Values are mean \pm standard error.

treatments exhibited higher nest success than in either the control or burn treatments. Notably, ground/shrub species had significantly lower nest success in burn treatments relative to the control and thin treatments. In contrast species nesting in the understory manifested higher nest success in thin treatments. Finally, both nest guilds displayed plasticity in nest heights post-treatment. Ground/shrub nesting species had higher nests in thin treatments, whereas understorynesting species modified nest placement in the burn treatments.

The tempo and magnitude of changes in overstory and understory structure was studied during the same time interval as our nest monitoring [26, 59, 60]. The single prescribed fire lowered seedling and sapling numbers, especially red maples (Acer rubrum) as well as nearly eliminating the leaf litter. The major disturbance in vegetation structure resulted in fewer nests being found in the burn treatment. However, by year 4, sapling density recovered to pre-treatment levels $[59,60]$. Percent cover in the shrub layer was dramatically reduced by the prescribe burn and never fully recovered by year 4 [60]. Percent ground cover (forbs and grasses) exceeded pre-treatment values at the end of the study [60]. Mechanical thinning resulted in an increase in understory recruitment of shadeintolerant species, e.g., Oak (Quercus spp.) [59]. Percent shrub cover declined after the first post-treatment year, but returned to baseline levels by the last year of the study. Some 
species, such as Rubus exceeded baseline levels of percent cover. There was an increase in forb and grass cover, but not nearly as great as in the burn treatment. The vegetation responses to prescribed fire and mechanical thinning mirrored the changes observed in fire- and thin-only. Two exceptions were greater amounts of grass and shrub cover relative to the other treatments.

The low number of nests discovered and monitored during the first 2 years post-treatment may be related to the reduced availability of nest sites. The burned sites had lower ground cover, sapling density and shrub cover in the first two post-treatment years. Moreover, shrub cover continued to decline through the duration of the study. Significant changes in vegetation structure in the thin and thin + burn treatment were only apparent by the end of the study [60]. The increase in coverage of ground cover (forbs and grasses) as well as an increase in sapling density and shrub cover provided habitat suitable for early successional species. It is noteworthy that we only discovered nests of the Gray Catbird, Blue-winged Warbler, Eastern Towhee, Indigo Bunting and Baltimore Orioles in the last two years of the study. Thus, there was a delay of two years before these early successional species colonized the treatment plots. The significant increase in total post-treatment nesting success in the thin and thin + burn treatments may be a reflection of the relatively rapid growth and recruitment of understory trees and shrubs in this treatment [59]. Furthermore, mechanical thinning reduced basal area and resulted in canopy gaps, which facilitated development of the shrub and understory vegetation by years 3 and 4 post-treatment [60]. The high nest success in the thin treatment contrasts with previous studies [22, 34]. Prescribed burning alone cleared the ground litter and much of the young tree and shrub cover, but the remaining overstory delayed recovery of the understory [23]. Thinning alone may have increased the available sunlight reaching the understory that was already established, but nesting success did not increase in this treatment relative to control. The increased nesting success in the thin + burn treatment supports the conclusion that the combination of these treatments may best reflect the structural conditions of the mixed-oak forest ecosystem from before the past century of fire suppression [54].

We were unable to monitor enough nests in the ground/shrub guild to obtain nesting success estimates for the two years of initial response in the thin and thin + burn treatments. This was not due to a lack of nest searching effort, but to a lack of active nests. The low number of ground/shrub nests discovered during this period may be a more telling sign than nesting success itself of the initial response of this guild to the entire experimental forest. As the forest understory recovered in the following two years, the number of nests discovered increased. During these response years the ground cover and understory growth was lowest in the burn treatment and this is reflected in the decreased nesting success of birds nesting on or near the ground. The lowered nesting success of ground and shrub nesting species is consistent with previous research [36].

In the first two post-treatment years, nesting success of the understory nesting guild was not significantly affected by the burning or thinning. During the extended response years, nests in this guild were highly successful in the combination thin + burn treatment, but were no different from control in the individual thin and burn treatments. The individual treatments having no significant effect on this guild is consistent with previous results $[38,40,41]$, but the significant increase in nesting success in the combination thin + burn treatment is a novel result.

Nest height appears to be a plastic trait that varies with treatment and nest guild. Ground nesting species adjusted nest height in response to mechanical thinning. Understory species selected higher locations for their nests in burned treatments. The latter result is consistent with the pattern found by Artman and Downhower [38] for Wood Thrush nests. The change in nest placement for species that are ground/shrub nesters reflects a change in the development of the shrub layer in the thin treatments. In contrast, the change in nest height in burned plots may be a response to increased forb and grass cover as well as an increase in sapling density.

Brown-headed Cowbird nest parasitism rates were negligible in this study. We found no parasitized nests in either the pre-treatment year or the first two years posttreatment. We discovered nests with cowbird eggs only in the last 2 years of the study. Our estimate of nest parasitism $(4.1 \%)$ is similar to that reported by Artman \& Downhower [38] in a burned habitat near our site. We attribute the low rates of parasitism to the position of these experimental forests within a contiguous control forest, with no extensive edge from agriculture or clearcut forest.

Our analysis emphasizes the importance of employing a before-after, control-impact experimental design combined with a long-term perspective when evaluating the responses of wildlife to forest management techniques. Conclusions based solely on a one or two-year study following treatments would lead to different management recommendations. For example, the combination of thinning followed by burning had an initial negative effect on part of the avian community. Yet, the patterns of daily survival and nest success recovered by years 3 and 4 , at least in the ground/shrub nesting species. In addition, the invasion of the thin + burn treatments by early successional species would have been missed with a short-term study. Moreover, after 4 years the thin + burn treatment resulted in the highest nest survival among all treatments. Based on the patterns of daily nest survival and nest we recommend a forest management scheme that involves periodic burning following partial harvest.

\section{ACKNOWLEDGEMENTS}

We thank D. Brown, D. Cohen, T. Dennis, A. Frank, C. Kanuckle, J. Michalak, A. Morford, J. Siekierski, A. Sites, and D. Weber for their diligence in the field. M. White, P. Allman, and T. Shaffer provided constructive comments on various aspects of the research. T. Shaffer provided guidance and SAS code to conduct the logistic exposure analysis. Dan Yaussy expertly handled logistics and facilitated the implementation of this research project. D. Hosack provided assistance while we worked at the Raccoon Ecological Management Area. This is Contribution Number 82 of the National Fire and Fire Surrogate Project (FFS), funded by the U.S. Joint Fire Science Program. This research was also supported by an equipment grant from Sandpiper Technologies to H.M.S. 


\section{REFERENCES}

[1] Robbins CS, Sauer JR, Greenberg RS, Droege S. Population declines in North American birds that migrate to the Neotropics. Proc Nat Acad Sci USA 1989; 86: 7658-62.

[2] Herkert JR. An analysis of midwestern breeding bird population trends: 1966-1993. Am Mid Nat 1995; 134: 41-50.

[3] Holmes RT. Understanding population change in migratory songbirds: long-term and experimental studies of Neotropical migrants in breeding and wintering areas. Ibis 2007; 149: S2-13.

[4] Robbins CS. Effects of forest fragmentation on bird communities. In: Degraaf RM, Evans KE, Eds. Management of North Central and Northeastern Forests for Non-game Birds. United States Department of Agriculture. General Technical Report NC-51; 1971; pp. 98-212

[5] Whitcomb RF, Robbins CS, Lynch JF, Whitcomb BL, Klimkiewicz MK, Bystrak D. Effects of forest fragmentation on the avifauna of the eastern deciduous forest. In: Burgess RL, Sharpe DM, Eds. Forest island dynamics in man-dominated landscapes. New York:Springer-Verlag 1981; pp. 125-205.

[6] Herkert JR, Knopf FL, Marzluff JM, Sallabanks R. Research needs for grassland bird conservation. In Avian Conservation: Research and Management, Island Press 1998; pp. 273-282.

[7] Robinson SK, Thompson III FR, Donovan TM, Whitehead DR, Faaborg J. Regional forest fragmentation and the nesting success of migratory birds. Science 1995; 267:1987-90.

[8] Dellinger RL, Wood PB, Keyser PD. Occurrence and nest survival of four thrush species on a managed central Appalachian forest. For Ecol Manage 2007; 243:48-58.

[9] Titterington RW, Crawford HS, Burgason BN. Songbird responses to commercial Clear-cutting in Maine, USA spruce-fir forests. J Wildl Manage 1979; 43: 602-9.

[10] Freedman B, Beauchamp C, McLaren IA, Tingley SI. Forestry management practices and populations of breeding birds in a hardwood forest in Nova-Scotia Canada. Can Field Nat 1981; 95: 307-11.

[11] Apfelbaum S, Haney A. Bird populations before and after wildfire in a Great Lakes (USA) pine forest. Condor 1981; 83: 347-54.

[12] Simon NPP, Schwab FE, Otto RD. Songbird abundances in clearcut and burned stands: a comparison of natural disturbance and forest management. Can J For Res 2002; 32: 1343-50.

[13] Beals EW. Forest bird communities in the Apostle islands of Wisconsin. Wils Bull 1960; 72:156-181.

[14] Annand EM, Thompson FR. Forest bird responses to regeneration practices in central hardwood forests. J Wildl Manage 1997; 61: 159-71.

[15] Robinson WD, Robinson SK. Effects of selective logging on forest bird populations in a fragmented landscape. Conserv Biol 1999; 13: 58-66.

[16] Artman VL, Southerland, EK, Downhower JF. Prescribed burning to restore mixed oak communities in southern Ohio: effects on breeding bird populations. Conserv Biol 2001; 15: 1423-34.

[17] Lance AN, Phinney M. Bird responses to partial retention timber harvesting in central interior British Columbia. For Ecol Manage 2001; 142:267-80.

[18] Van Horne, B. Density as a misleading indicator of habitat quality. J Wild Manage 1983; 47: 893-901.

[19] Remes V. Effects of exotic habitat on nesting success, territory density, and settlement patterns in the Blackcap (Sylvia atricapilla). Conserv Biol 2003; 17: 1127-33.

[20] Manolis JC, Anderson DE, Cuthbert FJ. Edge effect on nesting success of ground nesting birds near regenerating clearcuts in a forest dominated landscape. Auk 2002; 119: 955-70.

[21] Robertson BR, Hutto RL. Is selectively harvested forest an ecological trap for Olive-sided Flycatchers? Condor 2007; 109: 109-21.

[22] Gram WK, Porneluzi PI, Clawson RL, Faaborg J, Richter SC. Effects of experimental forest management on density and nesting success of bird species in Missouri Ozark forests. Conserv Biol 2003; 17: 1324-37.

[23] Abrams MD. Fire and the development of oak forests. Bioscience 1992; 42: 346-53

[24] Brawn JD. Effects of restoring oak savannas on bird communities and populations. Conserv Biol 2006; 20: 460-9.

[25] Pyne SJ, Andrews PL, Laven RD. Introduction to Wildland Fire: Fire Management in the United States. New York: John Wiley \& Sons 1984.
[26] Iverson LR, Hutchinson TF, Prasad AM, Peters MP. Thinning, fire and oak regeneration across a heterogeneous landscape in the eastern U.S.: 7 year results. For Ecol Manage 2008; 225: 3035-50.

[27] Sutherland EK. The history of fire in a southern Ohio secondgrowth mixed-oak forest. In: Pallardy SG, Cecich RA, Garret, HE, Johnson PS, Eds. Proceedings of the 11th Central Hardwoods Forest Conference; United States Department of Agriculture General Technical Report NC-188; 1997; pp. 172-83

[28] Lorimer CG, Chapman JW, Lambert WD. Tall understory vegetation as a factor in the poor development of oak seedlings beneath mature stands. J Ecol 1994; 82: 227-37.

[29] Hutto RL. Habitat selection by nonbreeding migratory land birds. In: Cody ML, Ed. Habitat Selection in Birds. Orlando, Florida: Academic Press 1985; pp. 455-76.

[30] Morse DH. Habitat selection in North American parulid warblers. In: Cody ML, Ed. Habitat Selection In Birds, Orlando, Academic Press 1985; pp. 131-54

[31] Schwilk DW, Keely, JE, Knapp EE, et al. The National Fire and Fire Surrogate study: effects of fuel reduction methods on forest vegetation structure and fuels. Ecol Appl 2009; 19: 285-304.

[32] Ohio Division of Forestry. Ohio Department of Natural Resources. Fire and fire surrogates study: prescribed fire and harvesting in mixed-oak forests. [cited 2009 May 14] Available from http://www.dnr.state.oh.us/forestry/Fire/prescribedfire1.htm

[33] Lanham JD, Keyser PD, Brose PH, Van Lear DH. Oak regeneration using the shelterwood-burn technique: management options and implications for songbird conservation in the southeastern United States. For Ecol Manage 2002; 155:143-52.

[34] King DI, Griffin CR, Degraaf RM. Effects of clearcutting on habitat use and reproductive success of the Ovenbird in forested landscapes. Conserv Biol 1996; 10: 1380-6.

[35] Peak RG, Thompson III, FR, Shaffer TL. Factors affecting songbird nest survival in riparian forests in a Midwestern agricultural landscape. Auk 2004; 121: 726-37.

[36] Aquilani SM, LeBlanc DC, Morrell TE. Effects of surface fires on ground- and shrub-nesting Neotropical migratory birds in a mature Indiana oak forest. Nat Areas J 2000; 20:317-24.

[37] Sperry J, George TL, Zack S. Ecological factors affecting response of Dark-eyed Juncos to prescribed burning. Wilson J Ornithol 2008; 120: 131-8.

[38] Artman VL, Downhower JF. Wood Thrush (Hylocichla mustelina) nesting ecology in relation to prescribed burning of mixed-oak forest in Ohio. Auk 2003; 120: 874-82.

[39] King DI, Degraaf RM. Bird species diversity and nesting success in mature, clearcut and shelterwood forest in northern New Hampshire. For Ecol Manage 2000; 129: 227-35.

[40] Duguay JP, Wood PB, Nichols JV. Songbird abundance and avian nest survival rates in forests fragmented by different silviculture treatments. Conserv Biol 2001; 15: 1405-15.

[41] Robinson SK, Robinson WD. Avian nesting success in a selectively harvested north temperate diciduous forest. Conserv Biol 2001; 15: 1763-71.

[42] Barber DR, Martin TE, Melchion, MA, Thill RE, Wigley TB. Nesting success of birds in different silvicultural treatments in southeastern U.S. pine forests. Conserv Biol 2001; 15: 196-207.

[43] Bourque J, Villard M. Effects of selective cutting and landscapescale harvesting on the reproductive success of two Neotropical migrant bird species. Conserv Biol 2001; 15: 184-95.

[44] Yaussy DA, Hutchinson TF, Sutherland EK. Structure, composition, and condition of overstory trees. In: Southerland EK, Hutchinson TF, Eds. Characteristics of Mixed-oak Forest Ecosystems in Southern Ohio Prior to the Reintroduction of Fire, United States Department of Agriculture General Technical Report NE-299, 2003; pp. 99-112.

[45] Martin TE, Guepel GR. Nest monitoring plots: methods for locating nests and monitoring success. J Field Ornithol 1993; 64: 507-19.

[46] Martin TE, Paine CR, Conway CJ, Hochachka WM, Allen P, Jenkins W. BBIRD Field Protocol. Montana Cooperative Wildlife Research Unit, University of Montana, Missoula, Montana, USA 1997

[47] Baicich PJ, Harrison CO. A guide to the nests, eggs, and nestlings of North American birds. $2^{\text {nd }}$ ed. San Diego:Academic Press 1997.

[48] Shaffer TL. A unified approach to analyzing nest success. Auk 2004; 121: 526-40. 
[49] Mayfield H. Nesting success calculated from exposure. Wilson Bull 1961; 73: 255-66.

[50] Miller HW, Johnson DH. Interpreting the results of the nesting studies. J Wildl Manage 1978; 42: 471-6.

[51] Johnson DH. Estimating nest success: the Mayfield method and an alternative. Auk 1979; 96: 651-61.

[52] Johnson DH, Shaffer TL. Estimating nest success: When Mayfield wins. Auk 1990; 1076: 595-600.

[53] Hosmer Jr., DW, Lemeshow S. Applied logistic regression. John Wiley and Sons: New York 1989

[54] Shaffer TL Thompson III FR. Making meaningful estimates of nest survival with model-based methods. Stud Avian Biol 2007; 34: 8495.

[55] Hazler CR. Mayfield Logistic Regression: A practical approach for analysis of nest survival. Auk 2004; 121: 707-16.
[56] Dinsmore SJ, White GC, Knopf FL. Advanced techniques for modeling avian nest survival. Ecology 2002; 83: 3476-88

[57] Lloyd JD, Tewksbury JJ. Analyzing avian nest survival in forests and grasslands: A comparison of the Mayfield and LogisticExposure methods. Stud Avian Biol 2008; 34: 96-104.

[58] SAS Institute. SAS 9.1. Open Metadata Interface: User's Guide. Cary: NC. 2004

[59] Albrecht MA, McCarthy BC. Effects of prescribed fire and thinning on tree recruitment in central hardwood forests. For Ecol Manage 2006; 226: 88-103.

[60] Waldrop TA, Yaussy DA, Phillips RJ, Hutchinson TF, Brudnak L, Boerner REJ. Fuel reduction treatments affect stand structure of hardwood forests in western North Carolina and southern Ohio, USA. For Ecol Manage 2008; 255: 3117-29.

(C) Streby and Miles; Licensee Bentham Open.

This is an open access article licensed under the terms of the Creative Commons Attribution Non-Commercial License (http://creativecommons.org/licenses/by$\mathrm{nc} / 3.0 /$ ) which permits unrestricted, non-commercial use, distribution and reproduction in any medium, provided the work is properly cited. 